\title{
Anita Perska-Tembłowska*
}

\section{PODSTAWOWE FORMY WSPÓŁPRACY MIĘDZYNARODO- WEJ JEDNOSTEK SAMORZĄDU TERYTORIALNEGO W POLSCE}

Z a r y s tr e ś c i: Jednostki samorządu terytorialnego w Polsce mogą podejmować współpracę z jednostkami samorządu terytorialnego położonymi poza granicami kraju. Współpraca międzynarodowa gmin, powiatów i województw może przyjąć różną formę. Celem głównym artykułu było określenie możliwości współpracy międzynarodowej jednostek samorządu terytorialnego w Polsce. Nastąpiła identyfikacja europejskich dokumentów wspierających współpracę międzynarodową jednostek terytorialnych. Ponadto rozpoznano polskie uwarunkowania prawne w zakresie zawierania porozumień o współpracy i przynależności do międzynarodowych zrzeszeń.

S Ł o w a k 1 u c z o w e: współpraca międzynarodowa, współpraca międzysamorządowa, jednostka samorządu terytorialnego, porozumienie, zrzeszenie międzynarodowe

K l a s y f i a c j a J E L: F 19, H 19

\section{WSTĘP}

Współpraca jednostek samorządu terytorialnego stanowi ważny aspekt ich funkcjonowania. Najczęściej autorzy podejmują problemy badawcze związane z przynależnością tych jednostek do trwałych form współpracy, m.in. do związków międzygminnych i stowarzyszeń. Analizie poddawane są przede wszystkim formy o zasięgu lokalnym, regionalnym i krajowym, podczas gdy jednostki samorządu terytorialnego mają również prawie zagwarantowaną

\footnotetext{
* Adres do korespondencji: Anita Perska-Trembłowska, Uniwersytet Ekonomiczny w Poznaniu, Wydział Zarządzania, Katedra Zarządzania Strategicznego, al. Niepodległosci 10, 61-875 Poznań, e-mail: anita.perska@ue.poznan.pl;
} 
możliwość podejmowania współpracy międzynarodowej. Potrzeba współpracy międzysamorządowej, w tym tej o charakterze międzynarodowym, wynika z nasilenia procesów takich jak: kryzys finansów publicznych, rosnące dysfunkcje samorządu terytorialnego ( $\mathrm{w}$ tym stosunkowo szeroka decentralizacja przy niewystarczającym zapewnieniu środków do wykonywania zadań publicznych), procesy demograficzne, problemy środowiskowe, procesy suburbanizacji, wzrost oczekiwań co do jakości świadczonych usług publicznych, rosnące znaczenie obszarów funkcjonalnych, konkurencja globalna [Perska, 2016, s. 3].

Celem artykułu jest wyjaśnienie, jakie możliwości podejmowania współpracy międzynarodowej posiadają jednostki samorządu terytorialnego. Analizą obejmuje się gminy, powiaty i województwa w Polsce. Zidentyfikowane zostają dokumenty europejskie, w których następuje wspieranie współpracy międzynarodowej jednostek terytorialnych. Analizie są poddane polskie akty prawne stanowiące o możliwych podstawowych formach współpracy międzynarodowej jednostek samorządu terytorialnego. Opis wyjaśniający oparty jest na analizie logicznej.

\section{STYMULOWANIE WSPÓŁPRACY MIĘDZYNARODOWEJ JED- NOSTEK SAMORZĄDU TERYTORIALNEGO W WYBRANYCH DOKUMENTACH EUROPEJSKICH}

Podstawy prawne współpracy międzynarodowej jednostek samorządu terytorialnego zostały zawarte $\mathrm{w}$ dokumentach uchwalonych na szczeblu międzynarodowym. Do istotnej ramy prawnej należy zaliczyć Europejską konwencję ramową o współpracy transgranicznej między wspólnotami i władzami terytorialnymi, sporządzoną w Madrycie dnia 21 maja 1980 r. Polska przystąpiła do Konwencji w dniu 19 stycznia 1993 r., a ratyfikowana została przez ówczesnego Prezydenta RP Lecha Wałęsę w dniu 10 marca 1993 r. [Kentnowska, 2012, s. 236]. W Konwencji za współpracę transgraniczną przyjmuje się „każde wspólnie podjęte działanie mające na celu umocnienie i dalszy rozwój sąsiedzkich kontaktów między wspólnotami i władzami terytorialnymi dwóch lub większej liczby umawiających się stron, jak również zawarcie porozumień i przyjęcie uzgodnień konicznych do realizacji takich zamierzeń" [Europejska konwencja ramowa o współpracy transgranicznej między wspólnotami i władzami terytorialnymi, 1980, art. 2, ust. 1]. Konwencja jako podstawę prawną współpracy transgranicznej wskazuje prawo wewnętrzne. Przyjętą w Konwencji formą współdziałania są porozumienia zawierane pomiędzy poszczególnymi państwami, a także wspólnotami i władzami terytorialnymi [Kentnowska, 2012, s. 236-237]. W załącznikach do Konwencji zawarto wzory porozumień międzypaństwowych w sprawie współpracy transgranicznej na szczeblu regionalnym i lokalnym, a także zarysy porozumień, umów i statutów, które mogą stanowić 
podstawę współpracy transgranicznej między wspólnotami i władzami regionalnymi [Izdebski, 2011, s. 444-445].

Kolejnym ważnym dokumentem jest uchwalona przez Radę Europy Europejska Karta Regionów Przygranicznych i Transgranicznych, która pomimo to, że nie stanowi prawa międzynarodowego, jest zbiorem dobrych praktyk [Kentnowska, 2012, s. 237]. Europejska Karta Regionów Przygranicznych i Transgranicznych została przyjęta w 1981 r. przez Stowarzyszenie Europejskich Regionów Granicznych ${ }^{1}$. Początkowo Karta nosiła nazwę Europejskiej Karty Regionów Przygranicznych, a obecna nazwa została przyjęta w 1995 r. w Szczecinie [CIE, 2014]. Podczas walnego zgromadzenia w Szczecinie w 1995 r. karta została znowelizowana i od tego czasu bywa nazywana kartą szczecińską (kolejna nowelizacja dostała dokonana w Szczecinie w 2004 r.) [Izdebski 2011, s. 445]. To z preambuły Europejskiej Karty Regionów Przygranicznych i Transgranicznych pochodzi określenie granic jako blizn historii, a współpraca transgraniczna określona jest jako ta, która ,pomaga w łagodzeniu niekorzystnych skutków istnienia owych granic (...). Współpraca ta obejmować powinna wszystkie dziedziny życia kulturalnego, społecznego i gospodarczego, a także rozwoju związanej z nimi infrastruktury" [Europejska Karta Regionów Przygranicznych i Transgranicznych, 1981, preambuła, s. 8].

Istotnym działaniem było wypracowanie w ramach Rady Europy Europejskiej Karty Samorządu Lokalnego, sporządzonej w Strasburgu w dniu 15 października 1985 r. Karta została ogłoszona w Dzienniku Ustaw w 1994 r., a w trakcie procesu ratyfikacji nieprawidłowo został przetłumaczony tytuł Karty - „Europejska Karta Samorządu Terytorialnego”, co sprostowano dopiero w 2006 r. [Izdebski, 2011, s. 109]. W tytule umowy zamiast wyrazu „Terytorialnego" powinien być wyraz „Lokalnego” (analogicznie w preambule i wskazanych w obwieszczeniu artykułach) [Obwieszczenie Ministra Spraw Zagranicznych, 2006]. Europejska Karta Samorządu Lokalnego zawiera ogólne zasady dotyczące samorządu lokalnego, który określony jest jako: „prawo i zdolność społeczności lokalnych, w granicach określonych prawem, do kierowania i zarządzania zasadniczą częścią spraw publicznych na ich własną odpowiedzialność i w interesie ich mieszkańców" [Europejska Karta Samorządu Terytorialnego, 1985, art. 3, pkt. 1]. W Karcie przyznano jednostkom samorządu lokalnego ogólne kompetencje do podejmowania i prowadzenia współpracy międzynarodowej [Kentnowska, 2012, s. 237]. W szczególności, przyznane w Karcie prawo społeczności lokalnych do zrzeszania się odnosi się również do przystępowania

\footnotetext{
${ }^{1}$ Stowarzyszenie Europejskich Regionów Granicznych (Association of European Border Regions) - międzynarodowa organizacja pozarządowa, powstała w 1971 r. w Anholt, w Niemczech. Jest to najstarsza organizacja regionalna w Europie [UKIE, 2014]. Należy do niej 95 członków reprezentujących około 163 europejskie regiony graniczne [AEBR Members across Europe, 2014]. Główna siedziba organizacji znajduje się w Gronau, Niemczech [AEBR Contact, 2014].
} 
społeczności lokalnych do międzynarodowych stowarzyszeń. Współpraca ze społecznościami innych państw powinna odbywać się na warunkach przewidzianych prawem [Europejska Karta Samorządu Terytorialnego, 1985, art. 10, pkt. 2 i 3$].$

Podobne uprawnienia w zakresie prowadzenia współpracy międzynarodowej przyznaje regionom Europejska Karta Samorządu Regionalnego, która wypracowana została w ramach Rady Europy (uchwalona przez IV Kongres Władz Lokalnych i Regionalnych Rady Europy, 3-5 czerwca 1997 r. w Strasburgu). Karta pozostaje wciąż projektem i można ją uznać za szczególny zbiór standardów „prawa miękkiego" (soft law) [Izdebski, 2011, s. 109]. Zgodnie z zawartymi w Karcie przepisami, region powinien prowadzić własną politykę i współpracę międzynarodową [Kentnowska, 2012, s. 237]. „W dziedzinach objętych ich kompetencjami regiony powinny być upoważnione do podejmowania współpracy międzyregionalnej lub transgranicznej zgodnie z procedurami nałożonymi przez prawo wewnętrzne. Współpraca ta powinna być prowadzona zgodnie z prawem wewnętrznym i międzynarodowymi zobowiązaniami państwa." [Europejska Karta Samorządu Regionalnego, 1997, art. 8, pkt. 1]. Ponadto w Karcie postuluje się prawo regionów do uczestnictwa w sprawach europejskich i międzynarodowych lub bycia reprezentowanym (przez przeznaczone specjalnie do tego celu ciała) w działaniach instytucji europejskich [Europejska Karta Samorządu Regionalnego, 1997, art. 10, pkt. 1]. W sytuacji wystąpienia konfliktu między współpracującymi regionami różnych państw, przede wszystkim w sprawach zawartych porozumień o współpracy regionalnej, stosuje się regulacje prawne Konwencji o koncyliacji i arbitrażu w ramach KBWE, sporządzonej w Sztokholmie 15 grudnia 1992 r. [Kentnowska, 2012, s. 237; Konwencja o koncyliacji i arbitrażu w ramach KBWE,1992].

Uwagę na pomoc samorządom w celu stymulacji współpracy we wszystkich dziedzinach zwraca Rezolucja Parlamentu Europejskiego z 15 marca 2007 r. w sprawie samorządów lokalnych i współpracy na rzecz rozwoju 2006/2235(INI). W Rezolucji następuje odniesienie się do doświadczenia samorządów we współpracy na rzecz rozwoju i korzyści z ich udziału. Uznaje się, że zaangażowanie samorządów lokalnych w politykę rozwoju jest niezbędne dla osiągnięcia milenijnych celów rozwoju ${ }^{2}$ oraz dla zapewnienia dobrego zarządzania [Rezolucja Parlamentu Europejskiego, 2007, pkt. 2]. Parlament Europejski zwraca się o „wsparcie i wzmocnienie bezpośredniej współpracy, jaką prowadzą euro-

\footnotetext{
${ }^{2}$ Milenijne Cele Rozwoju (Millennium Development Goals) - osiem celów, które zobowiązało się osiągnąc 189 członków ONZ w ramach Projektu Milenijnego ONZ. Cele miały zostać zrealizowane pomiędzy 1990 a 2015 rokiem. Ósmy cel odnosi się do współpracy różnych podmiotów: „Stworzenie globalnego partnerskiego porozumienia na rzecz rozwoju” [UNIC Projekt Milenijny Narodów Zjednoczonych, 2014]. Do milenijnych celów rozwoju i sposobów ich osiągnięcia nawiązuje w książce z 2005 r. Koniec z nędzą: Zadanie dla naszego pokolenia (The End of Poverty: Economic Possibilities for Our Time) Jeffrey David Sachs (amerykański ekonomista).
} 
pejskie samorządy lokalne z ich partnerami międzynarodowymi” [Rezolucja Parlamentu Europejskiego, 2007, pkt. 4]. Ponadto „podkreśla się konieczność wprowadzenia dialogu i stałych konsultacji pomiędzy UE i samorządami lokalnymi oraz ich stowarzyszeniami przedstawicielskimi na wszystkich szczeblach — krajowym, regionalnym, światowym" [Rezolucja Parlamentu Europejskiego, 2007, pkt. 16].

\section{FORMY WSPÓŁPRACY MIĘDZYNARODOWEJ JEDNOSTEK SAMORZĄDU TERYTORIALNEGO W DOKUMENTACH KRAJOWYCH}

Zgodnie z art. 172 ust. 2 Konstytucji RP ,jednostka samorządu terytorialnego ma prawo przystępowania do międzynarodowych zrzeszeń społeczności lokalnych i regionalnych oraz współpracy ze społecznościami lokalnymi i regionalnymi innych państw" [Konstytucja Rzeczypospolitej Polskiej, 1997, art. 172, ust. 2]. W ustawie z 8 marca 1990 r. o samorządzie gminnym, w ustawie z 5 czerwca 1998 r. o samorządzie powiatowym i ustawie z 5 czerwca 1998 r. o samorządzie województwa znajdują się ogólne zapisy dotyczące możliwości przystępowania przez jednostki samorządu terytorialnego do międzynarodowych zrzeszeń społeczności lokalnych i regionalnych poprzez odwołanie się do zasad zawartych w odrębnych przepisach [Ustawa, 1990, art. 84a; Ustawa, 1998a, art. 75a; Ustawa, 1998b, art. 76, ust. 3]. Ponadto w tzw. ustawach samorządowych wskazano na rolę organów stanowiących gminy, powiatu i województwa w zakresie podejmowania uchwał dotyczących współpracy międzynarodowej [Ustawa, 1990, art. 18, ust. 2, pkt. 12a; Ustawa, 1998a, art. 12, pkt. 9a; Ustawa, 1998b, art. 18, pkt. 14]. Uchwały w sprawie podjęcia współpracy zagranicznej odnaleźć można na stronie internetowej danej jednostki terytorialnej albo w biuletynie informacji publicznej tejże jednostki.

Umowy partnerskie są formą współdziałania praktycznie nieuregulowaną prawem krajowym, występuje duża swoboda w procedurze zawierania umów, we formalnej budowie, a także w nazwach używanych dla ich oznaczenia [Korczak, 2009, s. 335-336]. W praktyce spotkać można następujące nazwy: umowy partnerskie, porozumienia o partnerstwie miast, akt partnerstwa, dokument zawarcia związku partnerstwa, umowy o współpracy, a także umowy podjęte dla konkretnie oznaczonej przedmiotowo sfery działania (np. wymiana uczniów) [Korczak, 2009, s. 336; Kusiak-Winter, 2008, s. 329]. Według danych szacunkowych w obrocie prawnym funkcjonuje ok. 2 tys. umów [Korczak, 2009, s. 337].

W szczególności możliwość współpracy zagranicznej została wyeksponowana w ustawie z 5 czerwca 1998 r. o samorządzie województwa. Po pierwsze, w art. 12 ust. 2 ustawy o samorządzie województwa zapisano, że samorząd województwa realizując politykę jego rozwoju może również współpracować z orga- 
nizacjami międzynarodowymi i regionami innych państw, zwłaszcza sąsiednich [Ustawa, 1998b, art. 12, ust. 2]. Oprócz powyższych zapisów ustawy z 5 czerwca 1998 r. o samorządzie województwa, zawarto w niej rozdział pt. „Współpraca zagraniczna". Sejmik województwa jest zobowiązany do uchwalenia dokumentu „Priorytety współpracy zagranicznej województwa”, który określa [Ustawa, 1998b, art. 75]:

- główne cele współpracy zagranicznej,

- priorytety geograficzne przyszłej współpracy,

- zamierzenia co do przystępowania do międzynarodowych zrzeszeń regionalnych.

„Priorytety współpracy zagranicznej województwa” mogą być uchwalane oraz inicjatywy zagraniczne województwa (w tym w szczególności projekty umów o współpracy regionalnej) mogą być podejmowane za zgodą ministra właściwego do spraw zagranicznych i uchwały te zapadają bezwzględną większością głosów ustawowego składu sejmiku województwa [Ustawa, 1998b, art. 77, ust. 1 i 2]. Następnie wyżej wymieniona uchwała oraz zawarte umowy o współpracy regionalnej przesyłane są przez marszałka województwa do ministra właściwego do spraw zagranicznych oraz ministra właściwego do spraw administracji publicznej województwa [Ustawa, 1998b, art. 77, ust. 3].

Postulowane jest, żeby współpraca województwa ze społecznościami regionalnymi innych państw była prowadzona zgodnie z prawem wewnętrznym, polityką zagraniczną państwa i jego międzynarodowymi zobowiązaniami, w granicach zadań i kompetencji województwa [Ustawa, 1998b, art. 76, ust. 1]. Ponadto województwo uczestniczy w działalności międzynarodowych instytucji regionalnych oraz jest $\mathrm{w}$ nich reprezentowane na zasadach określonych w porozumieniu zawartym przez ogólnokrajowe organizacje zrzeszające jednostki samorządu terytorialnego [Ustawa, 1998b, art. 76, ust. 2].

Zasady, na jakich jednostki samorządu terytorialnego mogą przystępować do międzynarodowych zrzeszeń społeczności lokalnych i regionalnych określa ustawa z dnia 15 września 2000 r. o zasadach przystępowania jednostek samorządu terytorialnego do międzynarodowych zrzeszeń społeczności lokalnych i regionalnych [Ustawa, 2000, art. 1 ust. 1]. Akt ten odnosi się do wszystkich szczebli samorządu [Izdebski, 2011, s. 441]. Przez zrzeszenia, o których mowa w art. 1 ust. 1 niniejszej ustawy, rozumie się „organizacje, związki i stowarzyszenia powoływane przez społeczności lokalne co najmniej dwóch państw zgodnie z ich prawem wewnętrznym" [Ustawa, 2000, art. 1 ust. 2].

„Jednostki samorządu terytorialnego mogą przystępować do zrzeszeń i uczestniczyć w nich w granicach swoich zadań i kompetencji, działając zgodnie z polskim prawem wewnętrznym, polityką zagraniczną państwa i jego międzynarodowymi zobowiązaniami”, a ,przystąpienie do zrzeszenia nie może łączyć się z przekazaniem na jego rzecz lub na rzecz któregokolwiek ze zrzeszonych 
w nim członków wykonywania zadań publicznych przystępującej jednostki samorządu terytorialnego ani też nieruchomości lub majątkowych praw na dobrach niematerialnych przysługujących tej jednostce" [Ustawa, 2000, art. 2, ust. 1 i art. 3].

W ustawie z dnia 15 września 2000 r. o zasadach przystępowania jednostek samorządu terytorialnego do międzynarodowych zrzeszeń społeczności lokalnych i regionalnych określony jest tryb przystąpienia jednostki samorządu terytorialnego do zrzeszenia międzynarodowego. Postępowanie rozpoczyna się podjęciem przez organ stanowiący jednostki samorządu terytorialnego uchwały o przystąpieniu do zrzeszenia bezwzględną większością głosów ustawowego składu [Ustawa, 2000, art. 4, ust. 1]. Uchwała jest przekazana przez organ stanowiący jednostki samorządu terytorialnego (wraz ze statutem zrzeszenia, do którego zamierza wstąpić lub innym dokumentem ustalającym zasady działania tego zrzeszenia, listą jego członków oraz urzędowym tłumaczeniem tych dokumentów na język polski) ${ }^{3}$ ministrowi właściwemu do spraw zagranicznych za pośrednictwem wojewody, który dołącza opinię [Ustawa, 2000, art. 4, ust. 3 i 4]. Uchwała o przystąpieniu do zrzeszenia wchodzi w życie po uzyskaniu zgody ministra właściwego do spraw zagranicznych, który wyraża zgodę na przystąpienie do zrzeszenia lub odmawia takiej zgody $\mathrm{w}$ drodze decyzji administracyjnej [Ustawa, 2000, art. 4, ust. 2 i 5]. Z związku z powyższym jednostkom samorządu terytorialnego przysługują uprawnienia wynikające z Kodeksu Postępowania Administracyjnego, a także w zależności od potrzeby, z przepisów dotyczących sądownictwa administracyjnego [Izdebski, 2011, s. 443]. W przypadku, gdy nastąpi zmiana celów lub zasad działania danego zrzeszenia dalsze członkostwo jednostki samorządu terytorialnego w zrzeszeniu wymaga podjęcia uchwały przez organ stanowiący tej jednostki administracyjnej, a organy administracji rządowej dokonują swoje czynności w terminie 14 dni [Ustawa, 2000, art. 10, ust. 1]. Gdy pojawią się rozbieżności pomiędzy celami polityki zagranicznej państwa a polityką zrzeszenia, minister właściwy do spraw zagranicznych może cofnąć zgodę na przystąpienie do zrzeszenia [Ustawa, 2000, art. 10, ust. 2].

Po uzyskaniu zgody ministra właściwego do spraw zagranicznych na przystąpienie jednostki samorządu terytorialnego do międzynarodowego zrzeszenia, organ wykonawczy jednostki samorządu terytorialnego zobowiązany jest do niezwłocznego przedłożenia właściwemu terytorialnie wojewodzie, ministrowi właściwemu do spraw administracji publicznej, ministrowi właściwemu do spraw rozwoju regionalnego oraz ministrowi właściwemu do spraw zagranicznych informacji o przystąpieniu do zrzeszenia wraz z dokumentem świadczącym o członkostwie jednostki w zrzeszeniu (z tłumaczeniem na język polski sporzą-

\footnotetext{
${ }^{3}$ Sejmik województwa przedstawia także „Priorytety współpracy zagranicznej województwa” [Ustawa, 2000, art. 4, ust. 4].
} 
dzonym przez thumacza przysięgłego) ${ }^{4}$ [Ustawa, 2000, art. 6]. Minister właściwy do spraw administracji publicznej ma obowiązek ogłoszenia w Dzienniku Urzędowym Rzeczypospolitej Polskiej „Monitor Polski”, w drodze obwieszczenia, wykazu jednostek samorządu terytorialnego, które w poprzednim roku kalendarzowym przystąpiły do zrzeszenia, współtworzyły zrzeszenie lub z niego wystąpiły, oraz wykaz rozwiązanych zrzeszeń, do których jednostki te należały, wraz ze wskazaniem tych zrzeszeń [Ustawa, 2000, art. 9]. Wykaz jednostek samorządu terytorialnego, które zostały członkami zrzeszeń przed dniem wejścia w życie ustawy, został ogłoszony w Obwieszczeniu Ministra Spraw Wewnętrznych i Administracji z 4 października 2001 r. w sprawie wykazu jednostek samorządu terytorialnego, które zostały członkami międzynarodowych zrzeszeń społeczności lokalnych i regionalnych. W wykazie najczęstszym zrzeszeniem, do którego należały polskie samorządy, były euroregiony [Obwieszczenie Ministra Spraw Wewnętrznych i Administracji, 2001].

Euroregiony są przykładem samorządowego zrzeszania międzynarodowego, które równocześnie stanowią przykład współpracy transgranicznej [Izdebski, 2011, s. 445]. M. Rulińska [2004, s. 10] określa euroregion jako najwyższą formę organizacyjną współpracy transgranicznej. Chociaż brak oficjalnej definicji prawnej euroregionu, sformułowane w literaturze definicje odnoszą się do dwóch jego aspektów - wymiaru terytorialnego i funkcjonalnego [Łazutka, 2012, s. 404]. Jest to spójne z opinią z 17 stycznia 2007 r. sporządzoną przez Europejski Komitet Ekonomiczno-Społeczny w sprawie euroregionów, na podstawie której można przyjąć, że euroregion jest „stałą strukturą współpracy transgranicznej między bezpośrednio sąsiadującymi ze sobą władzami jednostek lokalnych i regionalnych usytuowanych wzdłuż wspólnych granic państwowych" [Opinia Europejskiego Komitetu Ekonomiczno-Społecznego, 2007, s. 1]. Głównym założeniem działań realizowanych przez członków euroregionu jest wspieranie rozwoju regionalnego, w tym wymiana doświadczeń i informacji dotyczących prawie wszystkich dziedzin (m.in. gospodarka, infrastruktura, handel, turystyka, ochrona zdrowia, działalność socjalna) [Malendowski, Szczepaniak, 2000, s. 11-18 za: Kentnowska, 2012, s. 243].

Pionierskie tego typu zrzeszenie - EUREGIO, zostało powołane w $1958 \mathrm{r}$. w ramach współpracy niemieckiej i holenderskiej, natomiast pierwszy euroregion z udziałem polskich gmin - Euroregion Nysa, powstał w 1991 r. (jako pierwszy euroregion w Europie Środkowo-Wschodniej) [Kentnowska, 2012, s, 243-244]. Obecnie istnieje 79 euroregionów, w tym w Polsce występuje ich 16 [MSZ, 2017; Czekaj, 2007, s. 20].

$\mathrm{Z}$ punktu widzenia formalnoprawnego euroregion nie stanowi odrębnej, samodzielnej organizacji, która posiada osobowość prawną, a jest jedynie do-

\footnotetext{
${ }^{4}$ Czynność stosuje się odpowiednio w przypadku wystąpienia jednostki samorządu terytorialnego
} ze zrzeszenia, a także w przypadku rozwiązania zrzeszenia [Ustawa, 2000, art. 7]. 
browolną wspólnotą interesów gmin i powiatów oraz ich organizacji [Korczak 2009, s. 338]. Obecnie obserwuje się spadek aktywności wielu euroregionów, a spora grupa myśli o przekształceniu w europejskie ugrupowanie współpracy terytorialnej (EUWT) [Łazutka, 2012, s. 415]. Powodem zaistniałej sytuacji jest przekonanie o ograniczonych możliwościach euroregionów wynikających z ich ram prawnych [MSZ, 2017].

\section{PODSUMOWANIE}

Współpraca międzynarodowa jednostek samorządu terytorialnego rozpatrywana jest jako uprawnienie do budowania i rozwoju relacji między wspólnotami terytorialnymi dwóch lub większej liczby państw. Polskie jednostki samorządu terytorialnego mają konstytucyjnie zagwarantowaną możliwość współpracy ze społecznościami lokalnymi i regionalnymi innych państw. Współpraca ta może następować poprzez zawieranie porozumień o współpracy z jednostkami terytorialnymi położonymi poza granicami Polski albo poprzez przynależność do międzynarodowych zrzeszeń społeczności lokalnych i regionalnych. W tzw. ustawach samorządowych przyznano organom stanowiącym gminy, powiatu, województwa kompetencje do podejmowania uchwał w sprawie uczestnictwa w międzynarodowych zrzeszeniach społeczności lokalnych i regionalnych, natomiast procedurę przystępowania do zrzeszeń regulują odrębne przepisy. Zgodnie z ustawą z 1999 r. o samorządzie województwa, samorząd ten realizując politykę rozwoju powinien współpracować z międzynarodowymi organizacjami i regionami innych państw. Ponadto obowiązkiem sejmiku województwa jest uchwalenie dokumentu „Priorytety współpracy zagranicznej województwa”, stanowiącego m.in. o celach współpracy zagranicznej i priorytetach geograficznych współpracy. Dalsze badania nad współpracą międzynarodową jednostek samorządu terytorialnego powinny obejmować identyfikację przynależności tychże jednostek do międzynarodowych zrzeszeń.

\section{LITERATURA}

AEBR Contact (2014), http://www.aebr.eu/en/contact.php [4.08.2014].

AEBR Members across Europe (2014), http://www.aebr.eu/en/members/border_regions.php [4.08.2014].

CIE (2014), http://www.cie.gov.pl/www/quest.nsf/DocByWykazZmian/5D5E3D1B2558C658C1256E860027C4FE?open [7.08.2014].

Czekaj M. (red.) 2007, Euroregiony na granicach Polski, Urząd Statystyczny we Wrocławiu Wydział Poligrafii, Wrocław.

Europejska Karta Regionów Przygranicznych i Transgranicznych (1981), http://archiwum-ukie. polskawue.gov.pl/HLP/files.nsf/0/5E37B3BC73FF3C33C1256E86004711F1/\$file/karta. pdf [4.08.2014]. 
Europejska Karta Samorządu Regionalnego (1997), http://www.google.pl/url?sa=t\&rc$\mathrm{t}=\mathrm{j} \& \mathrm{q}=\&$ esrc $=\mathrm{s} \&$ source $=\mathrm{web} \& \mathrm{~cd}=2 \& \mathrm{ved}=0 \mathrm{CCUQFj} \mathrm{AB} \& \mathrm{url}=\mathrm{http} \% 3 \mathrm{~A} \% 2 \mathrm{~F} \% 2 \mathrm{Fwww}$. karpacki.pl $\% 2 \mathrm{Fdownload} \% 2 \mathrm{Fgfx} \% 2 \mathrm{Fkarpacki} \% 2 \mathrm{Fpl} \% 2 \mathrm{Fdefaultopisy} \% 2 \mathrm{~F} 70 \% 2 \mathrm{~F} 10 \% 2$ F1\%2Feksr200804124345.doc\&ei=JuHgU-OBCKWo4gTspoHICw\&usg=AFQjCNFUY2bq93iSjKX_ZpDu2S2fsvDwdA\&bvm=bv.72197243,d.bGE [5.08.2014].

Europejska Karta Samorządu Terytorialnego z 15 października 1985 r., Dz.U. 1994, nr 124, poz. 607.

Europejska konwencja ramowa o współpracy transgranicznej między wspólnotami i władzami terytorialnymi z 21 maja 1980 r., Dz.U. 1993, nr 61, poz. 287.

Izdebski H. (2011), Samorząd terytorialny. Podstawy ustroju i działalności, LexisNexis Polska Sp. z o.o., Warszawa.

Kentnowska K. (2012), Rozwój form wspótpracy samorząów na poziomie międzynarodowym, [w:] Dolnicki B. (red.), Formy współdziałania jednostek samorządu terytorialnego, Lex a Wolters Kluwer business, Warszawa, s. 234-251.

Konstytucja Rzeczypospolitej Polskiej z 2 kwietnia 1997 r., Dz.U. 1997, nr 78 poz. 483.

Konwencja o koncyliacji i arbitrażu w ramach KBWE z 15 grudnia 1992 r., Dz.U. 1999, nr 98, poz. 1138.

Korczak J. (2009), Ewolucja form współdziałania jednostek samorządu terytorialnego na forum międzynarodowym, [w:] Sługocki J. (red.), Samorzad terytorialny w Polsce $i$ w Europie. Doświadczenia i dylematy dalszego rozwoju, Bydgoszcz, s. 331-345.

Kusiak-Winter R. (2008), Umowa miast partnerskich, [w:] Boć J., Dziewięcka-Bokun L., Umowy $w$ administracji, Kolonia Limited, Wrocław, s. 327-334.

Łazutka P. (2012), Specyfika euroregionów polsko-niemieckiego pogranicza w porównaniu do euroregionów na wschodniej granicy Polski, [w:] Dolnicki B. (red.), Formy współdziałania jednostek samorzadu terytorialnego, Lex a Wolters Kluwer business, Warszawa, s. 402415.

MSZ (2017), http://www.mfa.gov.pl/pl/polityka_zagraniczna/wymiar_samorzadowy/wspolpraca_zagraniczna_samorzadow_/euwt_i_euroregiony/europejskie_ugrupowania_wspolpracy_terytorialnej_euwt_i_euroregiony [20.04.2017].

Obwieszczenie Ministra Spraw Wewnętrznych i Administracji z 4 października 2001 r. w sprawie wykazu jednostek samorządu terytorialnego, które zostały członkami międzynarodowych zrzeszeń społeczności lokalnych i regionalnych, M.P. 2001, nr 35, poz. 569.

Obwieszczenie Ministra Spraw Zagranicznych z 22 sierpnia 2006 r. o sprostowaniu błędu, Dz.U. 2006, nr 154, poz. 1107.

Opinia Europejskiego Komitetu Ekonomiczno-Społecznego z 17 stycznia 2007 r. w sprawie euroregionów (2007/C 256/23).

Perska A. (2016), Czynniki kształtujące międzysamorządowa wspótpracę samorządów gminnych w Polsce, praca doktorska, Uniwersytet Ekonomiczny, Poznań, [maszynopis niepublikowany].

Rezolucja Parlamentu Europejskiego z 15 marca 2007 r. w sprawie samorządów lokalnych i współpracy na rzecz rozwoju (2006/2235(INI)), Dziennik Urzędowy Unii Europejskiej C301E/249, 13.12.2007, http://static.e-prawnik.pl/isap/iizue/2007/IiZUE2007_12_301_ E249.pdf [5.08.2014].

Rulińska M. (2004), Wspótpraca pomiędzy jednostkami samorządu terytorialnego, na zlecenie Fundacji Rozwoju Demokracji Lokalnej, Agencja Wydawniczo-Reklamowa MT, Warszawa.

UKIE, 2014, http://archiwum-ukie.polskawue.gov.pl/www/serce.nsf/0/257754E84270A9F3C1256E830060C6F0?Open\&RestrictToCategory $=[4.08 .2014]$.

UNIC Projekt Milenijny Narodów Zjednoczonych, 2014, http://www.unic.un.org.pl/projekt_milenijny/faq.php [5.08.2014]. 
Ustawa z 8 marca 1990 r. o samorządzie gminnym, Dz.U. 1990, nr 16, poz. 95.

Ustawa z 5 czerwca 1998a r. o samorządzie powiatowym, Dz.U. 1998, nr 91, poz. 578.

Ustawa z 5 czerwca 1998b r. o samorządzie województwa, Dz.U. 1998, nr 91, poz. 576.

Ustawa z 15 września 2000 r. o zasadach przystępowania jednostek samorządu terytorialnego do międzynarodowych zrzeszeń społeczności lokalnych i regionalnych, Dz.U. 2000, nr 91, poz. 1009 .

\title{
BASIC FORMS OF INTERNATIONAL COOPERATION OF SELF-GOVERNMENT UNITS IN POLAND
}

\begin{abstract}
Self-government units in Poland may cooperate with other self-government units, including those located outside the country. There are various forms of international cooperation of self-government units. The main aim of this paper was to analyze possibilities of international cooperation of self-government units in Poland. As the result of the analysis, the author has identified European documents supporting the international cooperation of territorial units. The author has identified legal conditions in terms of entering into cooperation agreements and the membership in international associations of territorial units in Poland too. The explaining description was based on the logical analysis.
\end{abstract}

Keywords: international cooperation, intercommunal cooperation, self-government unit, agreement, international association 
